\title{
THE EFFECT OF DIFFERENT KIND OF CITRUS ON THE QUALITY OF JELAWAT FISH (Leptobarbus hoevenii) NANIURA
}

\section{PENGARUH PENGGUNAAN JENIS JERUK YANG BERBEDA TERHADAP MUTU NANIURA IKAN JELAWAT (Leptobarbus hoevenii)}

\author{
Christine Natalia Hutapea ${ }^{1}$, Tjipto Leksono ${ }^{1,}$ N. Ira Sari ${ }^{1}$ \\ ${ }^{1}$ Teknologi Hasil Perikanan Fakultas Perikanan dan Kelautan Universitas Riau, Pekanbaru, Jl. HR \\ Soebrantas Km 12,5 Simpang Baru, Panam - Pekanbaru, Indonesia 28293 \\ Correspondence Author: hutapeachristine@yahoo.co.id
}

\begin{tabular}{ll}
\hline A R T I C L E I N F O \\
\hline \hline Submited & $: 15$ Desember 2018 \\
Revised & $: 17$ Januari 2019 \\
Approved & $:$ O6 Januari 2019
\end{tabular}

\section{Kata kunci:}

Asam jeruk,

Jelawat,

Naniura

\begin{abstract}
A B S T R A C T
This study aimed to know the effect of the using of different citrus on the quality of hoven's carp fish naniura and to determine the other kind of citrus to substitute the jungga (Citrus jambhiri) in naniura processing. The research method used was experimental composed as a non-factorial completely randomized design (CRD). The treatment conducted was the using of different kinds of citrus (jungga, lime, lemon) in the processing of naniura. The results showed that the different citrus used was significantly affecting the organoleptic values (appearance, odor, taste, and texture), $\mathrm{pH}$, water holding capacity, total plate number of bacteria, and a total of lactic acid bacteria. The best treatment is the use of lime (Citrus aurantifolia) with the characteristics of the appearance yelloworange color, quite bright, and not pale; the odor was not smelling fishy but smelling characteristically naniura; the taste was sour and spicy, and the texture was soft and not hard. Naniura used of lime has a $\mathrm{pH}$ value of 4.8, water holding capacity 53.2, total plate number $3.6 \times 10^{3} \mathrm{Cfu} / \mathrm{g}$, and lactic acid bacteria $4.3 \times 10^{5} \mathrm{Cfu} / \mathrm{g}$.
\end{abstract}

\section{PENDAHULUAN}

Ikan jelawat merupakan ikan yang memiliki nilai ekonomis penting yang mendiami perairan sungai di Kalimantan dan Sumatera (Kottelat dkk., 1993). Ikan ini tergolong dalam famili Cyprinidae (Saanin, 1968). Selain itu permintaan pasar terhadap ikan jelawat ini cukup tinggi dan salah satu jenis ikan air tawar lokal yang digemari sebagai ikan konsumsi oleh masyarakat (Hasan dan Firwara, 2014). Menurut Badan Pusat Statistik Provinsi Riau (2014), produksi ikan jelawat pada tahun 2014 mencapai 79,2 ton dan mengalami peningkatan di tahun 2015 menjadi 90,5 ton. Dengan demikian, ikan jelawat merupakan komoditas yang berpotensi untuk dikembangkan menjadi aneka produk olahan. Salah satu jenis olahan yang dapat dilakukan adalah dengan membuat naniura.

Naniura adalah makanan tradisional khas Batak Toba (Manik, 2013). Bahan baku utamanya adalah ikan mas yang diasamkan secara tradisional. Ikan mas merupakan jenis ikan 
dari famili Cyprinidae. Kesamaan famili dari ikan mas dan ikan jelawat membuat penulis tertarik untuk menggantikan jenis ikan mas dari Sumatera Utara yang umumnya digunakan dalam pembuatan naniura menjadi ikan jelawat dari Riau. Naniura merupakan makanan yang dibuat dengan pemberian larutan sari jeruk jungga pada ikan hingga menjadi lunak dan siap dikonsumsi tanpa dilakukan pemasakan (Manik dkk., 2015). Pada umumnya naniura disajikan untuk raja-raja terdahulu. Hal tersebut membuat makanan ini jarang ditemukan di kawasan perkotaan. Untuk itu perlu dilakukan pengembangan produk sebagai suatu upaya mempertahankan kebudayaan tersebut agar tetap lestari.

Penggunaan jenis jeruk yang berbeda akan mempengaruhi hasil akhir dari naniura. Hal ini disebabkan oleh jumlah dan kandungan dari masing-masing jeruk tersebut berbeda. Menurut Harbone (2007), jeruk jungga mengandung minyak atsiri yang dapat menimbulkan harum atau bau khas. Terpenoid yang terkandung dalam minyak atsiri menimbulkan bau harum atau bau khas dari tanaman. Minyak atsiri dapat digunakan sebagai antibakteri (Bassolé dan Juliani, 2012). Jeruk nipis memiliki banyak kandungan senyawa kimia yang bermanfaat seperti asam sitrat, minyak atsiri, flavonoid yang dapat berperan sebagai antibakteri dengan cara mendenaturasi protein dan merusak sel bakteri (Adindaputri dkk., 2013). Lemon mengandung asam sitrat, asam pantotenat, flavonoid, dan limonoid yang berfungsi sebagai aktivitas antibakteri dan antijamur (Batubara, 2017).

Asam organik utama yang terdapat dalam buah-buahan genus Citrus adalah asam sitrat dan asam malat dengan sedikit mengandung asam tartarat, asam benzoat, asam askorbat, dan asam laktat (Karadeniz, 2004). Penggunaan asam dalam pengolahan naniura mempunyai peranan penting sebagai antimikroba. Kondisi asam pada bahan pangan selain berpengaruh terhadap penurunan $\mathrm{pH}$ juga mempengaruhi aktivitas mikroorganisme (Fardiaz, 1992).

Jeruk jungga tergolong jenis jeruk yang sulit untuk ditemukan di Pekanbaru dan harganya cukup mahal. Jeruk jungga merupakan jenis jeruk yang tumbuh di daerah Sumatera Utara. Tersedianya jenis jeruk lain seperti jeruk nipis dan jeruk lemon yang lebih murah dan mudah ditemukan di pasaran memungkinkan untuk dijadikan sebagai alternatif pengganti jeruk jungga yang sulit ditemukan dan harganya yang mahal.

Berdasarkan hal tersebut penulis tertarik untuk melakukan penelitian tentang "Pengaruh Penggunaan Jenis Jeruk yang Berbeda terhadap Mutu Naniura Ikan Jelawat (Leptobarbus hoevenii)".

\section{METODE PENELITIAN}

\section{Bahan dan Alat}

Bahan baku yang digunakan dalam pembuatan naniura adalah ikan jelawat yang diperoleh dari Pasar Selasa Soebrantas dengan berat kisaran 1,3-1,7 kilogram per ekor. Berat fillet ikan jelawat yang digunakan yaitu 500 gram per ekor. Jumlah ikan jelawat yang digunakan adalah 9 ekor. Jeruk yang digunakan terdiri dari jeruk jungga, jeruk nipis, dan jeruk lemon. Bumbu tambahan yang digunakan dalam pembuatan naniura, yaitu: garam, bawang merah, bawang putih, andaliman, kemiri, batang kecombrang, cabai rawit, cabai merah, kacang tanah, dan kunyit. Bahan uji kimia yaitu aquades. Bahan uji mikrobiologi yaitu PCA (Plate Count Agar), MRSA (Methicillin Resistant Staphylococcus Aureus), dan $\mathrm{NaCl} \mathrm{0,9 \% .}$

Alat yang digunakan dalam pembuatan naniura ikan jelawat adalah wadah plastik, timbangan, mangkuk, sendok, kompor, blender, pisau, nampan, saringan, sendok penggorengan, pemeras jeruk. Alat kimia yang digunakan yaitu $\mathrm{pH}$ meter, gelas ukur, kertas saring. Alat mikrobiologi yang digunakan adalah pipet mikro, tabung reaksi, cawan petri, erlenmeyer, beaker glass, batang pengaduk, rak tabung reaksi, hot plate, inkubator, autoclave.

\section{Metode Penelitian}

Metode yang digunakan dalam penelitian ini adalah metode eksperimen yaitu melakukan pembuatan naniura dengan menggunakan jenis jeruk yang berbeda. Rancangan yang digunakan dalam penelitian ini adalah rancangan acak lengkap (RAL) non faktorial, terdiri dari 3 taraf perlakuan yaitu dengan penggunaan jenis jeruk yang berbeda terdiri dari jeruk jungga (Ju), jeruk 
nipis (Ni), dan jeruk lemon (Le). Semua percobaan diulang sebanyak 3 kali sehingga jumlah satuan percobaan sebanyak 9 unit percobaan.

Pada penelitian pendahuluan pertama diperoleh konsentrasi jeruk jungga terbaik 13\% dari berat ikan dengan kriteria rupa kuning orange agak menarik, aroma bumbu khas naniura, rasa asam dan pedas, serta tekstur yang lembut. Kemudian dilakukan penelitian pendahuluan kedua untuk mencari pengaruh konsentrasi dan lama pelumuran ikan jelawat di dalam jeruk jungga sehingga diperoleh konsentrasi asam jungga yang terbaik adalah 12\% dengan lama pelumuran 4 jam yaitu 3 jam untuk asam jungga dan garam serta 1 jam untuk pelumuran bumbu. Pada konsentrasi $12 \%$ dari berat ikan diperoleh kriteria rupa cerah, berwarna kuning orange, menarik, aroma jeruk dan bumbu khas naniura, tidak tercium bau amis, rasa asam dan pedas, serta tekstur daging yang lembut.

Parameter yang diamati dalam penelitian ini adalah uji mutu yang dilakukan oleh 25 panelis agak terlatih dengan memberi quisioner uji mutu secara organoleptik (rupa, aroma, rasa, tekstur), analisis $\mathrm{pH}$, daya ikat air, ALT, dan BAL.

\section{Prosedur Penelitian}

Prosedur pembuatan naniura (Pasaribu, 2015 dan hasil wawancara dengan Pangaribuan):

1. Ikan jelawat dibersihkan dari sisiknya kemudian difillet dan disayat-sayat untuk mempermudah penetrasi asam.

2. Ikan jelawat yang telah difillet segera dicuci dan ditiriskan lalu ditimbang untuk diperoleh berat $500 \mathrm{~g}$.

3. Perasan jeruk jungga, jeruk nipis, dan jeruk lemon dibuat dengan dibelah melintang kemudian diperas dengan menggunakan alat pemeras untuk mendapatkan sarinya. Setelah itu air perasan jeruk dipisahkan dari bijinya.

4. Semua bumbu yang terdiri dari bawang merah $25 \mathrm{~g}$, bawang putih $10 \mathrm{~g}$, kemiri $30 \mathrm{~g}$, cabe rawit $20 \mathrm{~g}$, cabe merah $10 \mathrm{~g}$, kacang tanah $50 \mathrm{~g}$ disangrai lalu dihaluskan menggunakan blender.

5. Batang kecombrang sebanyak $25 \mathrm{~g}$ direbus hingga lembek dan dihaluskan dengan menggunakan blender.

6. Andaliman sebanyak $25 \mathrm{~g}$ dihaluskan secara terpisah dengan menggunakan blender dan kunyit sebanyak $25 \mathrm{~g}$ diparut untuk mendapatkan air perasannya.

7. Air perasan jeruk jungga, jeruk nipis, dan jeruk lemon dengan konsentrasi $12 \%$ dari berat ikan yaitu sebanyak $60 \mathrm{ml}$ dimasukkan ke dalam wadah berbeda yang telah diisi oleh ikan dengan berat yang sama. Kemudian ditambahkan garam dengan konsentrasi $1 \%$ dari berat ikan $(5 \mathrm{~g})$ dengan cara dry salting dan diaduk hingga rata. Wadah ditutup dan diamkan selama 3 jam.

8. Setelah 3 jam, seluruh bumbu yang telah dihaluskan dilumuri pada daging ikan dan diaduk hingga rata. Kemudian didiamkan selama 1 jam.

\section{HASIL DAN PEMBAHASAN}

\section{Penilaian organoleptik}

Penilaian organoleptik pada pengaruh penggunaan jenis jeruk yang berbeda terhadap mutu naniura ikan jelawat (Leptobarbus hoevenii) ini dilakukan dengan menggunakan 25 panelis agak terlatih yaitu beberapa mahasiswa dari fakultas perikanan dan kelautan. Parameter yang diuji dalam pengujian organoleptik ini terdiri dari rupa, aroma, rasa, dan tekstur.

\section{Nilai rupa}

Berdasarkan Tabel 1. dapat dilihat bahwa nilai rupa naniura ikan jelawat dengan menggunakan jenis jeruk yang berbeda memiliki nilai tertinggi pada perlakuan $\mathrm{N}_{\mathrm{i}}(7,1)$ dengan kriteria berwarna kuning orange, cukup cerah, dan tidak pucat dan nilai terendah terdapat pada perlakuan $\mathrm{L}_{\mathrm{e}}(6,7)$ dengan kriteria berwarna kuning orange, kurang cerah, tidak pucat.

Berdasarkan hasil analisis variansi diperoleh hasil bahwa pengaruh penggunaan jenis jeruk yang berbeda berpengaruh nyata terhadap nilai rupa naniura ikan jelawat. 
Hasil uji lanjut BNJ diketahui bahwa nilai rupa naniura ikan jelawat dengan menggunakan jeruk nipis $\left(\mathrm{N}_{\mathrm{i}}\right)$ tidak berbeda nyata dengan penggunaan jeruk jungga $\left(\mathrm{J}_{\mathrm{u}}\right)$ tetapi berbeda nyata dengan lemon $\left(\mathrm{L}_{\mathrm{e}}\right)$.

Hal ini disebabkan oleh penggunaan jeruk nipis memberikan pengaruh warna yang baik pada rupa naniura ikan jelawat yaitu berwarna kuning orange, cukup cerah, dan tidak pucat. Namun pengaruh tersebut tidak terlihat jelas karena adanya penambahan bumbu dari luar. Keseragaman bumbu yang diberikan membuat ketiga perlakuan memiliki rupa yang hampir sama yaitu berwarna kuning orange yang berasal dari penggunaan kunyit pada naniura.

Menurut Winarno (1997), jeruk mengandung asam secara alami yaitu asam sitrat. Penambahan asam sitrat pada pengolahan pangan bertujuan untuk mempertegas warna dan rasa produk akhir.

\section{Nilai aroma}

Berdasarkan Tabel 2. dapat dilihat bahwa nilai aroma naniura ikan jelawat dengan menggunakan jenis jeruk yang berbeda memiliki nilai tertinggi pada $J_{u}(6,7)$ dengan kriteria aroma berbau jeruk, tidak tercium bau amis, berbau bumbu khas naniura dan nilai terendah terdapat pada perlakuan $\mathrm{L}_{\mathrm{e}}(6,4)$ dengan kriteria agak berbau jeruk, tidak tercium bau amis, berbau bumbu khas naniura.

Hasil analisis variansi menunjukkan bahwa penggunaan jenis jeruk yang berbeda berpengaruh nyata terhadap nilai aroma naniura ikan jelawat.

Hasil uji lanjut BNJ dapat dilihat bahwa nilai aroma naniura ikan jelawat dengan menggunakan jeruk jungga $\left(\mathrm{J}_{\mathrm{u}}\right)$ tidak berbeda nyata dengan penggunaan jeruk nipis $\left(\mathrm{N}_{\mathrm{i}}\right)$ tetapi berbeda nyata dengan lemon $\left(\mathrm{L}_{\mathrm{e}}\right)$.

Hal ini dikarenakan jeruk jungga memiliki aroma khas yang berasal dari minyak atsiri. Selain itu, penggunaan jeruk jungga pada naniura ikan jelawat dapat menghilangkan bau amis pada daging ikan. Perlakuan penggunaan jeruk jungga yang tidak berbeda nyata dengan jeruk nipis dikarenakan jeruk nipis juga mengandung minyak atsiri dan dapat menghilangkan bau amis. Sedangkan perlakuan jeruk jungga berbeda nyata dengan jeruk lemon dikarenakan aroma khas yang dihasilkan dari jeruk jungga berbeda dengan aroma yang dihasilkan dari jeruk lemon.

Menurut Harbone (2007), jeruk jungga mengandung minyak atsiri yang dapat menimbulkan harum atau bau khas. Terpenoid yang terkandung dalam minyak atsiri menimbulkan bau harum atau bau khas dari tanaman. Sifat-sifat minyak atsiri adalah berbau harum sesuai dengan aroma tanaman yang dihasilkannya, mempunyai rasa getir, pahit, atau pedas. Selanjutnya menurut Manalu (2009), adanya asam dapat mengurangi bau amis pada ikan mentah.

Menurut Hariana (2006), jeruk nipis mengandung minyak atsiri. Perasan jeruk nipis cukup efektif mengurangi bau amis pada ikan. Hal tersebut dikarenakan jeruk nipis mengandung asam sitrat dan asam askorbat, kedua asam tersebut dapat bereaksi dengan trimetilamin membentuk trimetil ammonium yang kemudian diubah menjadi bimetal ammonium, sehingga bau amis ikan berkurang (Poernomo dkk., 2004).

\section{Nilai rasa}

Berdasarkan Tabel 3. dapat ketahui bahwa nilai rasa naniura ikan jelawat dengan menggunakan jenis jeruk yang berbeda memiliki nilai tertinggi pada perlakuan $\mathrm{N}_{\mathrm{i}}(6,7)$ memiliki kriteria rasa asam dan pedas dan nilai terendah pada perlakuan $L_{e}(5,9)$ dengan kriteria rasa kurang asam dan pedas. Hasil analisis variansi diperoleh bahwa pengaruh jenis jeruk yang berbeda berpengaruh nyata terhadap nilai rasa naniura ikan jelawat.

Hasil uji lanjut BNJ dapat diketahui bahwa nilai rasa naniura ikan jelawat dengan menggunakan jeruk nipis $\left(\mathrm{N}_{\mathrm{i}}\right)$ berbeda nyata dengan penggunaan jenis asam jeruk lainnya. Hal ini dikarenakan adanya pengaruh perbedaan nilai $\mathrm{pH}$ dari masing-masing perlakuan. Nilai $\mathrm{pH}$ dari jeruk nipis yaitu 2,25 yang lebih rendah dari pada $\mathrm{pH}$ jeruk lemon yaitu 2,30 menghasilkan rasa naniura ikan jelawat yang lebih asam dari pada penggunaan jenis jeruk lainnya. Semakin rendah nilai $\mathrm{pH}$ dari suatu jeruk maka semakin asam rasa yang akan dihasilkan.

Menurut Winarno (2007), beberapa buah mengandung asam relatif dalam kadar tinggi seperti asam sitrat merupakan asam organik utama pada buah jeruk. Adanya asam tersebut 
menyebabkan rasa yang khas. Salah satu tujuan utama penambahan asam pada bahan makanan adalah untuk memberikan rasa asam. Unsur yang menyebabkan rasa asam adalah ion $\mathrm{H}^{+}$atau ion hidrogenium $\mathrm{H}_{3} \mathrm{O}^{+}$(Winarno, 1997). Menurut David (2006), jeruk nipis memiliki ciri khas yaitu rasa asam dengan $\mathrm{pH}$ 2,3-2,4. Selanjutnya menurut Batubara (2017), lemon memberikan rasa asam dengan $\mathrm{pH} 2-3$. 


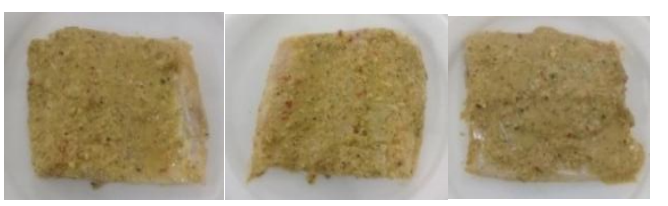

(a)

(b)

(c)

Gambar 1. Naniura ikan jelawat hasil (a) penggunaan jeruk jungga; (b) penggunaan jeruk nipis; (c) penggunaan jeruk lemon.

Tabel 1. Nilai rupa naniura ikan jelawat dengan menggunakan jenis jeruk yang berbeda

\begin{tabular}{ccccc}
\hline Jenis Jeruk & \multicolumn{3}{c}{ Ulangan } & \multirow{2}{*}{ Rata-rata } \\
\cline { 2 - 4 } & 1 & 2 & 3 & \\
\hline Jungga $\left(\mathrm{J}_{\mathrm{u}}\right)$ & 6,8 & 6,8 & 6,9 & $6,9^{\mathrm{ab}}$ \\
Nipis $\left(\mathrm{N}_{\mathrm{i}}\right)$ & 7,0 & 7,2 & 7,2 & $7,1^{\mathrm{b}}$ \\
Lemon $\left(\mathrm{L}_{\mathrm{e}}\right)$ & 6,8 & 6,7 & 6,6 & $6,7^{\mathrm{a}}$ \\
\hline
\end{tabular}

Tabel 2. Nilai aroma naniura ikan jelawat dengan menggunakan jenis jeruk yang berbeda

\begin{tabular}{ccccc}
\hline Jenis Jeruk & \multicolumn{3}{c}{ Ulangan } & Rata-rata \\
\cline { 2 - 4 } & 1 & 2 & 3 & \\
\hline Jungga $\left(\mathrm{J}_{\mathrm{u}}\right)$ & 6,8 & 6,7 & 6,7 & $6,7^{\mathrm{b}}$ \\
Nipis $\left(\mathrm{N}_{\mathrm{i}}\right)$ & 6,5 & 6,6 & 6,4 & $6,5^{\mathrm{ab}}$ \\
Lemon $\left(\mathrm{L}_{\mathrm{e}}\right)$ & 6,4 & 6,4 & 6,3 & $6,4^{\mathrm{a}}$ \\
\hline
\end{tabular}

Tabel 3. Nilai rasa naniura ikan jelawat dengan menggunakan jenis jeruk yang berbeda

\begin{tabular}{ccccc}
\hline Jenis Jeruk & \multicolumn{3}{c}{ Ulangan } & Rata-rata \\
\cline { 2 - 3 } & 1 & 2 & 3 & \\
\hline Jungga $\left(\mathrm{J}_{\mathrm{u}}\right)$ & 6,4 & 6,3 & 6,4 & $6,4^{\mathrm{b}}$ \\
Nipis $\left(\mathrm{N}_{\mathrm{i}}\right)$ & 6,7 & 6,8 & 6,8 & $6,7^{\mathrm{c}}$ \\
Lemon $\left(\mathrm{L}_{\mathrm{e}}\right)$ & 6,0 & 5,7 & 5,9 & $5,9^{\mathrm{a}}$ \\
\hline
\end{tabular}

Tabel 4. Nilai tekstur naniura ikan jelawat dengan menggunakan jenis jeruk yang berbeda

\begin{tabular}{ccccc}
\hline Jenis Jeruk & \multicolumn{3}{c}{ Ulangan } & Rata-rata \\
\cline { 2 - 4 } & 1 & 2 & 3 & \\
\hline Jungga $\left(\mathrm{J}_{\mathrm{u}}\right)$ & 6,8 & 6,6 & 6,7 & $6,7^{\mathrm{a}}$ \\
Nipis $\left(\mathrm{N}_{\mathrm{i}}\right)$ & 7,0 & 6,8 & 7,0 & $7,0^{\mathrm{a}}$ \\
Lemon $\left(\mathrm{L}_{\mathrm{e}}\right)$ & 6,9 & 6,8 & 6,8 & $6,9^{\mathrm{a}}$ \\
\hline
\end{tabular}

Tabel 5. Nilai $\mathrm{pH}$ naniura ikan jelawat dengan menggunakan jenis jeruk yang berbeda

\begin{tabular}{ccccc}
\hline Jenis Jeruk & \multicolumn{3}{c}{ Ulangan } & Rata-rata \\
\cline { 2 - 4 } & 1 & 2 & 3 & \\
\hline Jungga $\left(\mathrm{J}_{\mathrm{u}}\right)$ & 5,0 & 5,0 & 4,9 & $5,0^{\mathrm{b}}$ \\
Nipis $\left(\mathrm{N}_{\mathrm{i}}\right)$ & 4,7 & 4,8 & 4,7 & $4,8^{\mathrm{a}}$ \\
Lemon $\left(\mathrm{L}_{\mathrm{e}}\right)$ & 5,6 & 5,6 & 5,5 & $5,6^{\mathrm{c}}$ \\
\hline
\end{tabular}


Tabel 6. Nilai daya ikat air naniura ikan jelawat dengan menggunakan jenis jeruk yang berbeda

\begin{tabular}{ccccc}
\hline Jenis Jeruk & \multicolumn{3}{c}{ Ulangan } & Rata-rata \\
\cline { 2 - 3 } & 1 & 2 & 3 & \\
\hline Jungga $\left(\mathrm{J}_{\mathrm{u}}\right)$ & 36,1 & 38,1 & 39,2 & $56,7^{\mathrm{a}}$ \\
Nipis $\left(\mathrm{N}_{\mathrm{i}}\right)$ & 34,5 & 35,8 & 36,1 & $53,2^{\mathrm{a}}$ \\
Lemon $\left(\mathrm{L}_{\mathrm{e}}\right)$ & 39,8 & 42,1 & 43,2 & $62,5^{\mathrm{b}}$ \\
\hline
\end{tabular}

Tabel 7. Nilai angka lempeng total (sel/gram) naniura ikan jelawat dengan menggunakan jenis jeruk yang berbeda

\begin{tabular}{ccccc}
\hline Jenis Jeruk & \multicolumn{3}{c}{ Ulangan } & Rata-rata \\
\cline { 2 - 3 } & 1 & 2 & 3 & \\
\hline Jungga $\left(\mathrm{J}_{\mathrm{u}}\right)$ & $4,7 \times 10^{3}$ & $4,9 \times 10^{3}$ & $5,2 \times 10^{3}$ & $4,9 \times 10^{3 \mathrm{~b}}$ \\
Nipis $\left(\mathrm{N}_{\mathrm{i}}\right)$ & $3,6 \times 10^{3}$ & $3,9 \times 10^{3}$ & $3,2 \times 10^{3}$ & $3,6 \times 10^{3 \mathrm{a}}$ \\
Lemon $\left(\mathrm{L}_{\mathrm{e}}\right)$ & $6,4 \times 10^{3}$ & $6,9 \times 10^{3}$ & $7,3 \times 10^{3}$ & $6,9 \times 10^{3 \mathrm{c}}$ \\
\hline
\end{tabular}

Tabel 8. Nilai bakteri asam laktat (sel/gram) naniura ikan jelawat dengan menggunakan jenis jeruk yang berbeda

\begin{tabular}{ccccc}
\hline Jenis Jeruk & \multicolumn{3}{c}{ Ulangan } & Rata-rata \\
\cline { 2 - 4 } & 1 & 2 & 3 & \\
\hline Jungga $\left(\mathrm{J}_{\mathrm{u}}\right)$ & $2,6 \times 10^{5}$ & $2,1 \times 10^{5}$ & $2,7 \times 10^{5}$ & $2,5 \times 10^{5 \mathrm{~b}}$ \\
Nipis $\left(\mathrm{N}_{\mathrm{i}}\right)$ & $4,2 \times 10^{5}$ & $4,8 \times 10^{5}$ & $3,8 \times 10^{5}$ & $4,3 \times 10^{5 \mathrm{c}}$ \\
Lemon $\left(\mathrm{L}_{\mathrm{e}}\right)$ & $1,8 \times 10^{5}$ & $1,7 \times 10^{5}$ & $2,2 \times 10^{5}$ & $1,9 \times 10^{5 \mathrm{a}}$ \\
\hline
\end{tabular}




\section{Nilai tekstur}

Berdasarkan Tabel 4. dapat dilihat bahwa nilai tekstur naniura ikan jelawat dengan menggunakan jenis jeruk yang berbeda memiliki nilai tertinggi pada perlakuan $\mathrm{N}_{\mathrm{i}}(7,0)$ dengan kriteria daging ikan yang lembut dan tidak keras dan nilai terendah terdapat pada perlakuan $\mathrm{J}_{\mathrm{u}}$ $(6,7)$ dengan kriteria daging ikan yang agak lembut dan tidak keras.

Hasil analisis variansi menunjukkan bahwa penggunaan jenis jeruk berbeda berpengaruh nyata terhadap nilai tekstur naniura ikan jelawat.

Hasil uji lanjut BNJ dapat dilihat bahwa nilai tekstur naniura ikan jelawat dengan menggunakan jeruk nipis $\left(\mathrm{N}_{\mathrm{i}}\right)$ tidak berbeda nyata dengan penggunaan jenis asam jeruk lainnya. Tekstur naniura ikan jelawat yang lembut disebabkan oleh pengaruh asam yang dapat membuat nilai $\mathrm{pH}$ menjadi rendah. Semakin rendah nilai $\mathrm{pH}$, protein dalam daging ikan akan terdenaturasi dan mengakibatkan air dalam daging keluar sehingga tekstur daging ikan jelawat menjadi lebih lembut.

Menurut Borgstrom (1995), adanya asam dalam daging ikan akan menyebabkan denaturasi protein dan terjadinya koagulasi serta membebaskan air sehingga air pada daging ikan akan berkurang dan mengakibatkan daging ikan menjadi lebih lunak. Menurut Purnomo (1995), tekstur merupakan suatu kelompok sifat fisik yang ditimbulkan oleh elemen struktural bahan pangan yang dapat dirasa oleh alat peraba.

\section{Nilai pH}

Berdasarkan Tabel 5. dapat dilihat bahwa nilai $\mathrm{pH}$ naniura ikan jelawat dengan menggunakan jenis jeruk yang berbeda memiliki nilai tertinggi pada perlakuan $\mathrm{L}_{\mathrm{e}}(5,6)$ dan nilai terendah pada $\mathrm{N}_{\mathrm{i}}(4,8)$.

Hasil analisis variansi diperoleh bahwa penggunaan jenis jeruk yang berbeda berpengaruh nyata terhadap nilai $\mathrm{pH}$ naniura ikan jelawat.

Hasil uji lanjut BNJ diketahui bahwa nilai $\mathrm{pH}$ naniura ikan jelawat dengan menggunakan lemon $\left(L_{e}\right)$ berbeda nyata dengan penggunaan jenis jeruk lainnya. Hal ini disebabkan oleh kandungan asam-asam organik yang terdapat pada buah jeruk. Buah jeruk mengandung asamasam organik seperti asam sitrat. Semakin tinggi kadar asam dari buah jeruk maka semakin rendah nilai $\mathrm{pH}$ naniura ikan jelawat dan sebaliknya semakin rendah kadar asam pada buah jeruk maka semakin tinggi nilai $\mathrm{pH}$ yang dihasilkan.

Menurut Hariana (2006), jeruk nipis mengandung asam sitrat sebesar 7-7,6\%. Selanjutnya menurut Batubara (2017), dikatakan bahwa lemon mengandung asam sitrat sekitar 5\%. Berdasarkan hasil penelitian, jeruk nipis memiliki pH 2,25 dan lemon mempunyai $\mathrm{pH}$ 2,30. Menurut Gunawan (2006), semakin tinggi kandungan asam maka semakin rendah nilai $\mathrm{pH}$ suatu bahan pangan demikian juga semakin rendah kandungan asam maka semakin tinggi nilai $\mathrm{pH}$ dari bahan pangan.

Menurut Ikoh dalam Bethany (2016), pengasaman adalah suatu proses pengolahan yang dilakukan dengan cara pemberian asam dan bertujuan untuk mengawetkan melalui penurunan derajat pH. Menurut Martin dkk., (2000) asam organik seperti asam sitrat berpengaruh terhadap penurunan $\mathrm{pH}$, rasa, tekstur, serta kontaminasi mikroba pada bahan baku.

\section{Nilai daya ikat air}

Berdasarkan Tabel 6. dapat diketahui bahwa nilai daya ikat air naniura ikan jelawat dengan menggunakan jenis jeruk yang berbeda memiliki nilai tertinggi pada $L_{e}(62,5)$ dan nilai terendah pada $\mathrm{N}_{\mathrm{i}}(53,2)$. Hasil analisis variansi menunjukkan bahwa penggunaan jenis jeruk yang berbeda berpengaruh nyata terhadap nilai daya ikat air naniura ikan jelawat.

Hasil uji lanjut BNJ diketahui bahwa nilai daya ikat air naniura ikan jelawat dengan menggunakan jeruk lemon $\left(\mathrm{L}_{\mathrm{e}}\right)$ berbeda nyata dengan penggunaan jenis asam jeruk lainnya tetapi penggunaan jeruk jungga $\left(\mathrm{J}_{\mathrm{u}}\right)$ tidak berbeda nyata dengan jeruk nipis $\left(\mathrm{N}_{\mathrm{i}}\right)$. Hal ini disebabkan oleh pemberian asam yang menyebabkan nilai $\mathrm{pH}$ dari naniura menurun. Nilai $\mathrm{pH}$ yang rendah akan menyebabkan protein terdenaturasi sehingga kemampuan protein dalam mengikat air menjadi rendah dan jumlah air yang keluar lebih banyak. Semakin rendah nilai $\mathrm{pH}$ maka nilai daya ikat air pada naniura ikan jelawat juga semakin rendah. 
Menurut Davidek dkk., (1990) penggunaan asam dapat menurunkan $\mathrm{pH}$ yang dapat menyebabkan penurunan daya ikat air pada jaringan daging ikan sehingga air dapat keluar dari daging ikan. Kemampuan mengikat air suatu bahan pangan sangat dipengaruhi oleh tingkat keasaman daging (Soeparno, 2005).

\section{Angka lempeng total}

Berdasarkan Tabel 7. Dapat diketahui bahwa nilai angka lempeng total naniura ikan jelawat dengan menggunakan jenis jeruk yang berbeda memiliki nilai tertinggi pada perlakuan $\mathrm{L}_{\mathrm{e}}$ yaitu $6,9 \times 10^{3} \mathrm{sel} / \mathrm{gram}$ dan terendah pada perlakuan $\mathrm{N}_{\mathrm{i}}$ yaitu $3,6 \times 10^{3} \mathrm{sel} / \mathrm{gram}$.

Hasil analisis variansi menunjukkan bahwa penggunaan jenis jeruk yang berbeda berpengaruh nyata terhadap nilai angka lempeng total naniura ikan jelawat.

Hasil uji lanjut BNJ menunjukkan bahwa penggunaan jeruk lemon $\left(\mathrm{L}_{\mathrm{e}}\right)$ berbeda nyata dengan penggunaan jenis jeruk lainnya. Hal ini disebabkan oleh adanya pengaruh pemberian asam pada naniura ikan jelawat. Kondisi asam yang tinggi akan menurunkan nilai $\mathrm{pH}$ dari naniura sehingga bakteri yang tidak tahan terhadap asam akan mati. Hal ini diakibatkan oleh pengaruh asam yang dapat merusak sel dari bakteri tersebut. Selain pengaruh asam yang dapat menurunkan nilai $\mathrm{pH}$, adanya kandungan antibakteri seperti flavonoid dari jeruk yang dapat menyebabkan jumlah mikroba yang tumbuh menjadi lebih sedikit.

Menurut Febrian (2016), bahwa asam sitrat dari buah jeruk memiliki pH 2,2-2,5 yang dapat menghambat pertumbuhan atau membunuh bakteri dengan cara merusak sel bakteri sehingga dapat mengurangi pertumbuhan mikroba terutama mikroba patogen. Sehingga kondisi asam pada bahan pangan selain berpengaruh terhadap penurunan $\mathrm{pH}$, juga mempengaruhi aktivitas mikroba. Menurut Winarno (2007), bahwa jumlah asam yang cukup akan menyebabkan denaturasi protein bakteri, oleh karena itu beberapa mikroba sensitif terhadap asam. Hal ini berkaitan dengan tinggi atau rendahnya konsentrasi ion hydrogen $(\mathrm{pH})$.

Menurut Buckle dkk., (1987) asam paling sedikit mempunyai dua pengaruh antimikroorganisme, yaitu pertama karena pengaruhnya terhadap $\mathrm{pH}$ dan yang lainnya adalah sifat keracunan yang khas dari asam-asam yang tidak terurai yang beragam untuk asam-asam yang berlainan.

Menurut Adindaputri dkk., (2013) jeruk nipis juga mengandung flavonoid yang dapat berperan sebagai antibakteri dengan cara mendenaturasi protein dan merusak sel bakteri. Selain itu adanya kandungan minyak atsiri dari buah jeruk dapat digunakan sebagai antibakteri (Bassolé dan Juliani, 2012).

\section{Bakteri asam laktat}

Berdasarkan Tabel 8. dapat dilihat bahwa nilai bakteri asam laktat naniura ikan jelawat dengan menggunakan jenis jeruk yang berbeda memiliki nilai tertinggi pada perlakuan $\mathrm{N}_{\mathrm{i}}$ yaitu $4,3 \times 10^{5} \mathrm{sel} /$ gram dan terendah pada perlakuan $\mathrm{L}_{\mathrm{e}}$ yaitu $1,9 \times 10^{5} \mathrm{sel} / \mathrm{gram}$.

Pada hasil analisis variansi menunjukkan bahwa pengaruh penggunaan jenis jeruk yang berbeda terhadap mutu naniura ikan jelawat berpengaruh nyata terhadap nilai bakteri asam laktat.

Hasil uji lanjut BNJ dapat diketahui bahwa penggunaan jeruk nipis $\left(\mathrm{N}_{\mathrm{i}}\right)$ berbeda nyata dengan penggunaan jenis jeruk lainnya. Hal ini disebabkan oleh adanya kandungan asam-asam organik dari jeruk nipis yang menyebabkan menurunnya nilai $\mathrm{pH}$ dari naniura ikan jelawat. Kondisi $\mathrm{pH}$ yang rendah akan mendukung pertumbuhan dari bakteri asam laktat.

Menurut Winarno (2007), asam di dalam makanan dapat dihasilkan dengan menambahkan kultur pembentuk asam, atau menambahkan langsung asam ke dalam makanan misalnya asam sitrat. Air jeruk mengandung asam yang masing-masing mempunyai pengaruh yang berbeda-beda sebagai bahan pengawet. Hal ini sebagian besar disebabkan oleh tinggi atau rendahnya konsentrasi ion hydrogen $(\mathrm{pH})$.

Menurut Silalahi (2006), proses pembuatan naniura memungkinkan bakteri asam laktat berkembang seperti Lactobacillus. Lactobacillus merupakan sumber probiotik yang menguntungkan bagi kesehatan dan menghasilkan bakteriosin yang dapat menghambat pertumbuhan bakteri patogen. 
Menurut Buckle dkk., (1987) adanya mikroorganisme tertentu dapat tumbuh dengan adanya garam dan asam, seperti Lactobacillus.

\section{KESIMPULAN}

Perlakuan penggunaan jenis jeruk yang berbeda berpengaruh nyata terhadap nilai organoleptik (rupa, aroma, rasa, tekstur), $\mathrm{pH}$, daya ikat air, angka lempeng total, dan bakteri asam laktat.

Perlakuan terbaik adalah penggunaan jeruk nipis (Citrus aurantifolia) dengan karakteristik rupa berwarna kuning orange, cukup cerah, dan tidak pucat, aroma berbau jeruk, tidak tercium bau amis, berbau bumbu khas naniura, rasa asam dan pedas, tekstur lembut dan tidak keras.

Naniura ikan jelawat dengan hasil penggunaan jeruk nipis memiliki nilai $\mathrm{pH} 4,8$, daya ikat air 53,2, angka lempeng total $3,6 \times 10^{3} \mathrm{sel} / \mathrm{gram}$, dan bakteri asam laktat 4,3 x $10^{5} \mathrm{sel} / \mathrm{gram}$. Dengan demikian, jeruk nipis dapat digunakan sebagai alternatif pengganti jeruk jungga, karena harganya lebih murah dan lebih mudah ditemukan dipasaran.

\section{REKOMENDASI}

Berdasarkan hasil penelitian ini, penulis menyarankan untuk mengganti penggunaan jeruk jungga yang langka di Pekanbaru agar digantikan dengan penggunaan jeruk nipis dan melakukan pengujian proksimat pada naniura ikan jelawat dengan menggunakan jenis jeruk yang berbeda.

\section{DAFTAR PUSTAKA}

Adindaputri, Zenia, Nunuk P., Ivan A.W. 2013. Pengaruh Ekstrak Kulit Jeruk Nipis (Citrus aurantifolia Swingle) Konsentrasi 10\% Terhadap Aktivitas Enzim Glukosil transferas Streptococcus mutans. Majalah Kedokteran Gigi. 20 (2). 126-131.

Badan Pusat Statistik Provinsi Riau. $2014 . \quad$ dalam https://riau.bps.go.id/statictable/2017/01/25/322/produksidan-nilai perikanan-perairan umum-tambak-dan-kolam-keramba-menurut-jenis-2014 2015. html [6 Oktober 2018]

Bassolé, I.H.N., dan Juliani, H.R. 2012. Essential oils in combination and their antimicrobial properties. Molecules.17(4): 3989.

Batubara, N.A. 2017. Efek Air perasan buah jeruk lemon (Citrus lemon) terhadap laju aliran, nilai $\mathrm{pH}$ saliva dan jumlah koloni Staphylococcus aureus (in vivo). [Skripsi]. Medan: Universitas Sumatera Utara.

Bethany. 2016. Pengaruh Jenis Asam Dan Konsentrasi Asam Jeruk Terhadap Mutu Fisik, Kimia, dan Organoleptik Ikan Mas Naniura. J. Rekayasa Pangan dan Pert., Vol.4 No. 4

Borgstorm, G. 1995. Prinsiples of Food Science. Food Microbiology and Chemisry. MacMillan Ltd. London.

Buckle, K.A., Edward, R.A., Fleet, G.H., Wooton, M. 1987. Ilmu Pangan. Penerjemah Hari Purnomo dan Adiono. Jakarta: Universitas Indonesia.

David, F. R. 2006. Jeruk Nipis Secara Umum. Edisi kedua belas. Salemba Empat, Jakarta.

Davidek, J., Velisek, J., dan Pokorny. 1990. Chemical Changes During Food Processing. Development in Food Science 21.Elsevier.

Fardiaz, S. 1992. Mikrobiologi Pangan I. Gramedia Pustaka. Jakarta.

Febrian, G. M., Julianti, E., Rusmarilin. 2016. Pengaruh Berbagai Jenis Asam Jeruk dan Lama Perendaman Terhadap Mutu Ikan Mas Naniura. Jurnal Rekayasa Pangan dan Pert 4 (4): 472

Gunawan, A. 2006. Food Combining. Gramedia Pustaka Utama. Jakarta. 
Harbone, J.B. 2007. Metode Fitokimia Penuntun Cara Modern Menganalisis Tumbuhan. Terjemahan: K. Padmawinata dan I. Sudira. Bandung: ITB Press.

Hariana, A. 2006. Tumbuhan Obat danKhasiatnya. Edisi Pertama. Penebar Swadaya, Jakarta.

Hasan, H. R.E.I., dan Firwara, R. 2014. Pertumbuhan Ikan Jelawat (Leptobarbus hoevenii) dengan padat tebar yang berbeda dengan sistem mina padi. Jurnal Ruaya (3) :1.

Karadeniz, F. 2004. Main organic acid distribution of authentic citrus juices in turkey. Turk J Agric.For 28: 267-271.

Kottelat, M., A.J. Whitten, S.N. Kartikasari, S. Wirjoatmodjo. 1993. Freshwater fishes of Western Indonesia and Sulawesi. Periplus Edition (HK), Jakarta.

Manalu, M. B. F. 2009. Memperkenalkan Naniura Makanan Khas Batak Sebagai Hidangan Appetizer. Majalah Ilmiah Panorama Nusantara, edisi VII.

Manik, M. 2013. Pengaruh natrium benzoat dan lama penyimpanan pada suhu kamar terhadap mutu "dengke mas naniura" (ikan mas naniura). Prosiding Seminar Nasional Yusuf Benseh. Polteknik Negeri Lhokseumawe.

Manik, M., Kaban, J., Silalahi, J., dan Ginting M. 2015. Komposisi proksimat dengke naniura yang diolah dari ikan mas (Crypinus carpio) hasil budidaya. Prodising Seminar Nasional Kimia.

Martin, R. E., Carter, E. P., Flick G. J., dan Davis, L. M. 2000. Marine and Freshwater Products Handbook. Technomic Publishing Company, Inc. USA.

Pasaribu, R. 2015. Studi Penerimaan Konsumen Terhadap Naniura Ikan Mas (Cyprinus carpio) dengan Asam Jungga (Citrus hytrix DC) Berbeda. [Skripsi]. Pekanbaru: Universitas Riau.

Poernomo D, Sugeng HS, dan Agus W. 2004. Pemanfaatan asam cuka, jeruk nipis (Citrus aurantifolia) dan belimbing wuluh (Averrhoa blimi) untuk mengurangi bauamis petis ikan layang (Decapterus spp). Bogor: FPIK-IPB.

Purnomo, H. 1995. Aktifitas Air dan Peranannya dalam Pengawetan Pangan. UI Press. Jakarta.

Saanin, S.T. 1968. Taksonomi dan Kunci Identifikasi Ikan Jilid I dan II. Bina Cipta. Bandung.

Silalahi, J. 2006. Makanan Fungsional. Yogyakarta: Penerbit Kanisius.

Soeparno, 2005. Ilmu dan Teknologi Daging. UGM-Press,. Yogyakarta.

Winarno, F.G. 1997. Kimia Pangan dan Gizi.PT. Gramedia Pustaka Utama. Jakarta. 415 2007. Teknobiologi Pangan. Bogor. Mbrio biotekindo/mbrio press. 